\title{
KRITIK SOSIAL DALAM TIGA CERPEN DI KORAN MANUNTUNG TAHUN 1980-AN DI KALIMANTAN TIMUR
}

\section{SOCIAL CRITICISM IN THREE MANUNTUNG NEWSPAPERS' SHORT STORIES IN THE 1980S IN EAST KALIMANTAN}

\author{
Dwi Hariyanto \\ Kantor Bahasa Provinsi Kalimantan Timur \\ Jalan Batu Cermin 25, Sempaja Utara, Samarinda \\ Pos-el: haridwije@yahoo.com
}

*) Naskah diterima: 14 September 2020; direvisi: 14 Septemberl 2020; disetujui: 19 Oktober 2020

\begin{abstract}
Abstrak
Pengkajian ini memaparkan gambaran kritik sosial dalam tiga cerpen yang dimuat dalam koran di Kalimantan Timur pada tahun 1980-an, yaitu "Nomer", "Suatu Sore di Pinggiran Desa", dan "Tatkala Takbir Menggema". Fenomena sosial di masyarakat dalam cerpen yang dimuat dalam media cetak berbentuk koran ini layak diungkapkan. Pengungkapan fenomena sosial dalam tiga cerpen tersebut sangat diperlukan untuk melihat kondisi sosial masyarakat di tahun 1980-an karena pada tahun-tahun tersebut dapat dikatakan sebagai awal kemunculan karya sastra berbentuk cerpen dalam media cetak berbentuk koran di Kalimantan Timur. Metode kualitatif digunakan penulis untuk mengungkapkan gambaran sosial yang terjadi pada tahun 1980-an di Kalimantan Timur. Pendekatan sosiologi sastra digunakan sebagai alat untuk mengungkapkan masalah sosial dalam tiga cerpen ini. Namun, sebagai pijakan awal, penulis akan memanfaatkan struktural untuk mengungkapkan salah satu unsur intrinsik yang terdapat dalam karya cerpen yang dibahas. Hasil kajian menyimpulkan bahwa keadaan sosial masyarakat di tahun 1980-an adalah masalah kemiskinan, disorganisasi keluarga, generasi muda dalam masyarakat modern, pelanggaran terhadap norma masyarakat, kependudukan, lingkungan hidup, dan birokrasi.
\end{abstract}

Kata kunci: Kalimantan Timur, kritik sosial, koran, cerpen

\begin{abstract}
This study presents a picture of social criticism in three short stories published in newspapers in East Kalimantan in the 1980s, namely "Nomer", "Suatu Sore di Pinggiran Desa", and "Tatkala Takbir Menggema". Social phenomena in the society in those short stories are worth disclosing. It is necessary to see the social conditions in the society in the 1980s. It can be considered to be the beginning of literary works in the form of short stories in print media of newspapers in East Kalimantan. The author uses qualitative methods to reveal the social picture in the 1980s in East Kalimantan. It also uses the sociological approaches to literature to show social problems in these three short stories. However, as a starting point, the writer will use the structure to reveal one of the intrinsic elements in the short stories. It shows that the social conditions in the society in the 1980s are poverty, family disorganization, young people in the modern society, violations of social norma, demography, environment, and bureaucracy.
\end{abstract}

Keywords: East Kalimantan, social criticism, newspaper, short stories 


\section{PENDAHULUAN}

Cerita pendek adalah salah satu bentuk karya sastra di luar puisi yang sering mendapat tempat di media cetak. Selain majalah, media cetak berbentuk koran pun ada yang menyediakan tempat untuk bentuk karya sastra yang berupa cerita pendek. Keterbatasan ruang adalah salah satu kendala kemunculan cerpen dalam koran. Namun, tidak sedikit koran yang masih aktif menampilkan cerpen dalam medianya meskipun tidak setiap hari.

Demikian juga di Kalimantan Timur, cerita pendek sempat mendapat ruang yang cukup baik di media cetak yang berbentuk koran. Keberadaan cerpen dalam koran di Kalimantan Timur belum sebanding dengan keberadaan puisi yang lebih dahulu mendapat tempat di media cetak berbentuk koran. Pada tahun 1946, koran Masyarakat Baru-koran yang terbit di Kalimantan Timur-sudah mulai memuat karya sastra yang berbentu sajak atau puisi (Dachlan melalui Pernyata, 2002:3). Pada tahun 1970an, terbit majalah mingguan yang kemudian menjelma menjadi koran Sampe di Kalimantan Timur. Selain itu, juga ada koran Gelora Mahakam yang terbit di Tenggarong. Akan tetapi, karya sastra berbentuk cerpen belum ada dalam terbitan kedua koran tersebut. Media cetak pada waktu itu masih memuat karya sastra yang berupa puisi. Namun, hal tersebut tidak menyurutkan semangat penulis cerpen di Kalimantan Timur. Menurut Katoeng, keberadaan cerpenis di Kaltim sudah ada pada tahun 1950-1960-an. Mereka adalah Achmad Noor, Ardin Katoeng, dan Hiefnie Effendy (Katoeng melalui Pernyata, 2002:15). Namun, untuk karya sastra berbentuk cerpen, data paling awal yang dapat dilacak menunjukkan keberadaan cerpen pada tahun 1988 di dalam koran Manuntung.

Perkembangan cerpen Indonesia kontemporer pada satu dasawarsa 1980-an banyak ditentukan oleh perkembangan media massa (Mahayana, 2006:26). Selain majalah Horison, koran-koran yang terbit di ibu kota semacam Kompas, Republika, Media Indonesia, Suara Karya Minggu, Pelita, dan lain lain menyediakan ruang untuk karya sastra yang berupa cerpen. Di tahun 1980-an akhir, tepatnya di 1988 karya sastra berupa cerpen terdeteksi keberadaanya di koran lokal Kalimantan Timur, yaitu Manuntung. Keberadaan cerpen di koran Manuntung bahkan hampir dijumpai dalam setiap terbitannya. Hal ini menunjukkan bahwa keberadaan karya sastra berupa cerpen di koran Manuntung ditunggu oleh para pembaca koran di Kalimantan Timur.

Intesitas pemuatan cerpen di koran Manuntung yang cukup tinggi menunjukkan bahwa masyarakat Kalimantan Timur memerlukan media hiburan. Salah satu media hiburan yang dapat dijumpai dengan mudah adalah cerpen di koran. Sejalan dengan pendapat Horatius yang mengungkapkan bahwa karya sastra itu bersifat dulce et utile (Teeuw, 2015:7), karya-karya cerpen yang dimuat dalam koran Manuntung menampilkan hal yang sejalan dengan pendapat tersebut. Karya-karya cerpen dalam koran tersebut diharapkan dapat memberi hiburan sekaligus bermanfaat bagi masyarakat pembacanya. Selain memberikan salah satu hiburan, pesan-pesan yang tersirat dalam cerpen-cerpen di koran Manuntung dapat memberikan pencerahan melalui tema-tema cerita yang beragam. Tema-tema yang diangkat meliputi masalah-masalah keseharian yang berupa percintaan, lingkungan, masalah sosial, dan lain sebagainya. Masalah sosial dalam cerpen-cerpen yang dimuat pada tahun 1980-an ini menarik dikaji untuk melihat gambaran sosial masyarakat di Kalimantan Timur pada era tersebut.

Fenomena sosial yang diangkat para pengarang dalam karyanya dapat menjadi 
salah satu tolok ukur kondisi sosial masyarakat pada waktu itu. Hal ini sejalan dengan pandangan bahwa karya sastra adalah tiruan kehidupan. Karya sastra tidak dapat dilepaskan dari kehidupan masyarakatnya. Demikian pula dalam cerpen-cerpen yang dimuat dalam koran Manuntung, gambaran sosial masyarakat yang dalam cerita pendek adalah gambaran sosial masyarakat yang ditangkap oleh pengarang di lingkungan sosialnya pada masa itu.

Masalah sosial akan selalu ada dalam kehidupan manusia. Gambaran kehidupan sosial dapat kita ambil dari sebuah cerita fiksi yang berkembang. Hal itu dapat kita lakukan karena pengarang adalah bagian dari masyarakat. Karya sastra tidak sekadar karya imajinatif, tetapi karya yang bersumber pada fakta yang ada dalam masyarakat dan dikembangkan dengan dengan imajinasi pengarang.

Pengkajian tiga cerpen yang dimuat dalam koran Manuntung pada tahun 1980an ini diharapkan dapat memberikan gambaran masalah sosial yang dihadapi oleh masyarakat pada tahun-tahun tersebut.

\section{LANDASAN TEORI}

Sosiologi sastra adalah cabang penelitian sastra yang bersifat reflektif. Penelitian ini banyak diminati oleh peneliti yang ingin melihat sastra sebagai cermin kehidupan masyarakat (Endraswara, 2013:77). Sastra yang mengandung pesan kritik, dapat disebut sebagai sastra kritik, biasanya lahir di tengah masyarakat yang mengalami masalah atau ketidakberesan dalam kehidupan sosial bermasyarakat (Nurgiyantoro, 2005: 331). Hal tersebut menunjukkan bahwa fenomena sosial di masyarakat adalah salah satu pemicu kelahiran karya sastra. Masalahmasalah sosial dalam masyarakat akan selalu ada. Masalah-masalah sosial tersebut kemudian diolah pengarang menjadi karya kreatif yang berupa sastra.
Sosiologi sastra adalah pendekatan yang mempertimbangkan segi-segi kemasyarakatan (Damono, 1978:2). Pendapat lain yang menguatkan adalah sosiologi sastra merupakan cabang ilmu sastra yang mendekati sastra dari hubungannya dengan kenyataan sosial (Hartoko dan Rahmanto: 1986:129). Berdasarkan dua pendapat di atas, dapat disimpulkan bahwa sosiologi sastra adalah pendekatan yang tepat untuk mengungkap kritik sosial dalam cerpen "Nomer", "Suatu Sore di Pinggiran Desa", dan "Tatkala Takbir Menggema".

Menurut Wellek dan Warren, sosiologi sastra melibatkan sosiologi pengarang, sosiologi karya, dan sosiologi pembaca. Sosiologi pengarang mencakup latar belakang sosial, sumber ekonomi, dan ideologi pengarang yang terlihat dari berbagai kegiatan pengarang di luar karya sastra. Sosiologi karya mencakup isi karya sastra, tujuan serta hal-hal lain yang tersirat dalam karya sastra itu sendiri, dan yang berkaitan dengan masalah sosial. Sosiologi pembaca mencakup permasalahan pembaca dan dampak sosial karya sastra (Saraswati, 2003:12-16). Sejalan dengan Wellek dan Werren, Damono pun mengungkapkan hal yang senada. Ada dua kecenderungan dalam telaah sosilogis terhadap karya sastra. Pertama, pendekatan yang berdasarkan anggapan bahwa sastra merupakan cermin proses sosial-ekonomis belaka. Pendekatan ini bergerak dari faktor-faktor luar sastra untuk membicarakan sastra. Kedua, pendekatan yang mengutamakan teks sastra sebagai bahan penelaahan. Metode yang digunakan dalam sosiologi sastra adalah analisis teks untuk mengetahui strukturnya, kemudian digunakan untuk memahami lebih dalam gejala sosial yang terdapat dalam masyarakat (Damono, 1978:2). Berdasarkan pendapat di atas, pengkajian ini memfokuskan kajian pada sosiologi karya untuk mengungkapkan isi karya sastra, 
tujuan, dan hal-hal lain yang berkaitan dengan masalah sosial yang tersirat dalam cerpen "Nomer", "Suatu Sore di Pinggiran Desa", dan "Tatkala Takbir Menggema".

Kepincangan-kepincangan yang dianggap sebagai masalah sosial oleh masyarakat bergantung pada sistem nilai sosial masyarakat tersebut. Beberapa persoalan yang sering dianggap sebagai masalah sosial adalah kemiskinan, kejahatan, disorganisasi keluarga, generasi muda dalam masyarakat modern, peperangan, pelanggaran terhadap norma masyarakat, kependudukan, lingkungan hidup, dan birokrasi (Soekanto, 2015:319 -342). Berdasarkan masalahmasalah sosial tersebut akan terlihat masalahmasalah sosial apa saja yang diangkat dalam tiga cerpen koran Manuntung yang terbit di Kalimantan Timur pada tahu 1980-an.

\section{METODE PENELITIAN}

Metode dilakukan dengan langkahlangkah kerja yang diatur sebagaimana yang berlaku bagi penelitian-penelitian pada umumnya. Penerapan metode ilmiah harus mempertimbangkan sifat sastra yang memperlihatkan gejala yang universal tetapi sekaligus khusus atau unik (Suratno dalam Jabrohim (Ed), 2003:12-13).

Metode penelitian dibagi menjadi dua macam, yaitu metode pengumpulan data dan metode analisis data. Metode dan teknik pengumpulan data adalah cara yang merupakan perpanjangan indra manusia karena tujuannya adalah mengumpulkan fakta-fakta empirik yang terkait dengan masalah penelitian. Metode analisis data merupakan seperangkat cara atau teknik penelitian yang merupakan perpanjangan dari pikiran manusia karena fungsinya bukan untuk mengumpulkan data, melainkan untuk mencari hubungan antardata (Faruk, 2012:13-25).

Untuk mengungkapkan kritik sosial dalam pengkajian ini, penulis mengguna- kan metode kualitatif. Metode kualitatif ini memberikan perhatian kepada data alamiah, data dalam hubungannya dengan konteks keberadaannya. Melalui metode kualitatif, gejala sosial yang relevan dapat dilibatkan dalam penelitian ini (Ratna, 2004: 47). Selain itu, penulis juga akan memanfaatkan sosiologi sastra sebagai pendekatan dalam pengkajian ini.

\section{HASIL DAN PEMBAHASAN}

\section{Ringkasan Cerita}

Cerpen berjudul "Nomer" Karya Sumarlan Jamaah menceritakan tokoh Doel Kamid, seorang buruh bangunan, yang berusia empat puluh enam tahun. Ia bersama istri dan lima orang anaknya tinggal di permukiman kumuh dekat lokasi pembuangan sampah. Rumahnya yang kecil dan sempit terbuat dari bahan-bahan bekas kandang ayam. Keluarga kecil Doel Kamid adalah keluarga tidak mampu sehingga segala kebutuhan yang diperlukan banyak yang tidak terpenuhi.

Doel Kamid memiliki mimpi menjadi orang kaya dengan cara yang cepat dan tanpa bekerja keras. Keinginan menjadi kaya membuatnya harus mengorbankan semua harta bendanya untuk dipertaruhkan. Kondisi ekonomi keluarga yang tidak stabil dan cenderung minus membuat Doel dan istrinya bertengkar. Doel meminta istrinya untuk bersabar, tetapi istrinya yang sudah terlanjur marah akhirnya merobek kertaskertas ramalan angka. Doel yang masih berharap kepada kertas-kertas berisi nomor tersebut pun tertidur dan bermimpi tentang nomor-nomor yang bisa membawa keberuntungannya.

Doel terkejut melihat tumpukan uang di depannya. Ia tidak pernah melihat uang sebanyak itu. Keluarga dan tetangga sekitar mengerumuninya. Ia membagikan sebagian kecil uang kepada para tetangganya. Kehi- 
dupan keluarga Doel Kamid berubah. Rumah baru yang cukup besar dan dilengkapi dengan perabotan mewah. Selain itu, sepeda motor dan warung kelontong ia dapatkan melalui uang itu. Namun, semua mimpi itu berantakan saat istrinya membangunkannya dari tidur karena anaknya kembali sakit panas.

Cerpen "Suatu Sore di Pinggiran Desa" karya C.H. Iskandar menceritakan nasib dua orang buruh di penggergajian kayu. Mereka adalah Bidin dan Muin. Mereka memiliki latar belakang keluarga dan masalah yang berbeda. Bidin bekerja keras untuk melunasi utang dan menghidupi keluarganya. Istrinya sedang hamil tua dan akan melahirkan beberapa hari ke depan. Bidin memikirkan biaya persalinan sang istri. Muin adalah sosok yang belum berumah tangga. Muin memahami kesulitan Bidin dan menawarkan bantuan kepada Bidin. Namun, upaya bantuanya diabaikan oleh Bidin. Mereka pun melanjutkan pekerjaan mereka sore itu.

Akan tetapi, di tengah kesibukan bekerja, pekerjaan mereka dihentikan oleh kedatangan bos mereka, yaitu Pak Hamid. Pak Hamid dan Kepala Desa mengabarkan bahwa penggergajian kayu tersebut akan ditutup karena surat izinnya belum lengkap.

Cerpen "Tatkala Takbir Menggema" menceritakan kepulangan sosok Ratih. Setelah sekian lama meninggalkan kampung halamannya, Ratih memberanikan diri pulang dengan segala kepedihan. Pada awalnya Ratih adalah sosok gadis yang polos dan rajin mengaji. Ratih pun tumbuh menjadi gadis cantik jelita di sebuah kampung yang penuh dengan kedamaian.

Namun, saat menginjak usia remaja, Ratih yang polos terbuai oleh bujuk rayu sosok pemuda bernama Rey. Ratih pun sangat mencintai Rey dan terbuai bujuk rayunya. Ratih tak kuasa menolak saat Rey mengajaknya untuk menikah. Akan tetapi,
Ratih ternyata mengambil keputusan yang salah. Rey ternyata seorang pengangguran yang suka berjudi. Ratih pun menjual perhiasaannya untuk keperluan sehari-hari bahkan sampai perhiasaannya habis Rey tak kunjung mendapatkan pekerjaan. Rey meninggalkan Ratih dalam kondisi tak memiliki uang. Ratih terpaksa menjadi seorang wanita kupu-kupu malam untuk memenuhi kebutuhannya.

Ratih menyesali keputusannya mengikuti Rey dan menjadi kupu-kupu malam. Di akhir cerita, dengan berbekal uang secukupnya, Ratih kembali ke kampung halamannya dan memulai kehidupan seperti yang dulu ketika masih di desa. Ia ingin melupakan kenangan pahit yang ia dapatkan selama di kota. Ratih pergi meninggalkan kota untuk bertaubat dan kembali ke jalan yang benar.

\section{Tema}

Cerpen "Nomer" Karya Sumarlan Jamaah ini bertema masalah ekonomi di sebuah keluarga. Doel Kamid dan keluarganya mengalami kesulitan ekonomi dalam rumah tangga mereka. Gambaran rumah yang sempit dan utang yang menumpuk menunjukkan kesulitan keluarga tersebut dalam memenuhi kebutuhan hidup seharihari.

Belum lagi permintaan anaknya yang lain, biaya pengobatan si Ragil dan tagihan hutang yang menumpuk. Kekalutan Doel Kamid memuncak sampai ke ubun-ubun, membuat kepalanya pusing. Masih jelas terngiang pertengkaran dengan isterinya sore tadi (Jamaah, 1988).

Kutipan itu menunjukkan bahwa Doel Kamid mengalami kesulitan dalam masalah keuangan. Ia bertengkar dengan istrinya karena banyak kebutuhan yang tidak terpenuhi. Anak yang sakit dan utang yang 
menumpuk membuat tekanan kehidupan Doel makin meningkat. Cerpen ini menggambarkan kehidupan keluarga Doel Kamid yang hidup serba kekurangan.

Tema yang diangkat dalam cerpen "Suatu Sore di Pinggiran Desa" karya C.H. Iskandar ialah kehidupan masyarakat pinggiran yang diwakili oleh para buruh potong kayu. Sosok Bidin digambarkan sebagai buruh lepas pemotong kayu diperusahaan penggergajian kayu.

Kedua pekerja "shaw mill" itu lalu terdiam, menatap kayu hasil gergajian mereka dengan perasaan puas bercampur letih. Membayangkan upah yang bisa mereka bawa ke rumah dengan disambut anak dan istri yang telah menunggu dengan setia. Bercanda dan berkumpul bersama kembali, membuang keletihan akibat bekerja sehari penuh, dan mengumpulkan kesegaran baru untuk bekerja esok harinya (Iskandar, 1988).

Kutipan tersebut menunjukkan bahwa kondisi sosial pekerja yang berasal dari kalangan menengah ke bawah. Kerja keras yang mereka lakukan untuk menghidupi dan memenuhi kebutuhan hidup keluarga. Mereka sangat bergantung pada perusahaan tempatnya bekerja untuk menghasilkan uang.

Cerpen "Tatkala Takbir Menggema" mengangkat penyesalan tokoh Ratih. Hal tersebut ditunjukkan melalui alur cerita yang diawali dengan kesedihan dan penyesalan tokoh Ratih. Gambaran penyesalan tokoh Ratih dapat dilihat dalam kutipan berikut.

Ratih tercenung mendengar alunan takbir yang terdengar di mana-mana. Alunan yang suci itu membuat Ratih menyadari akan keadaan dirinya. Ia memang orang yang begitu kotor dan menjijikan. Ia telah masuk dalam kubangan lumpur dosa dan jurang kenistaan. Tapi adakah Tuhan masih mau menerima taubat dari orang yang akan bangkit dari lembah nan hitam. Suara takbiran kian menyentuh hati Ratih, air matanya meleleh jatuh satusatu. Di mana setiap tetesan air mata yang jatuh membawa beribu-ribu penyesalan (Lestari, 1989).

Kutipan tersebut menunjukkan penyesalan tokoh Ratih atas segala dosa yang telah dibuatnya. Ratih sadar dan berniat untuk bertaubat serta kembali ke jalan yang benar. Penyesalan Ratih juga muncul saat Ratih sadar telah dibohongi oleh sosok Rey yang tidak bertanggung jawab. Gambaran penyesalan dan kekecewaan Ratih terhadap sosok Rey dapat dilihat dalam kutipan berikut.

Kebahagiaan Ratih mulai pudar saat datang seorang pemuda yang bernama Rey. Ratih masih ingat saat kekasih yang sangat dicintainya ternyata adalah orang yang paling bejat. Tak lebih dari iblis berwujud manusia. Karena Rey adalah orang yang tega menenggelamkan Ratih dalam jurang kenistaan. Dunia yang tak pernah diimpikan oleh Ratih. Hingga karena Rey pula Ratih tega meninggalkan kedua orang tuanya (Lestari, 1989).

Dan ia tak mau menjadi mangsa untuk yang kedua kalinya dari ular-ular kota. Biarlah cerita dirinya akan menjadi kenangan pahit dalam hidupnya dan sebagai cambuk dalam melangkahkan kaki pada hari depan (Lestari, 1989).

Kutipan-kutipan tersebut menunjukkan bahwa Ratih sangat menyesal telah menuruti kemauan sang kekasih. Seseorang lelaki yang tidak bertanggung jawab yang 
menyebabkan Ratih menjadi perempuan malam.

\section{Kritik Sosial}

Persoalan sosial yang terjadi di dalam kehidupan bermasyarakat adalah sumber inspirasi dalam mengolah cerita. Cerita yang dihasilkan oleh pengarang memiliki keterkaitan dengan masalah sosial masyarakat di tempat pengarang berada. Berikut adalah masalah-masalah sosial yang diungkapkan oleh pengarang dalam cerpen "Nomer", "Suatu Sore di Pinggiran Desa", dan "Tatkala Takbir Menggema."

\subsection{Kemiskinan}

Miskin dalam KBBI berarti tidak berharta atau serba kekurangan. Sementara itu, Soekanto mengungkapkan bahwa kemiskinan adalah suatu keadaan seseorang yang tidak sanggup memelihara dirinya sendiri (2015:325). Kemiskinan adalah masalah utama dalam masyarakat. Dampak dari kemiskinan akan menimbulkan atau memicu masalah sosial yang lain. Hal ini terlihat dari tiga cerpen yang mengangkat masalah kemiskinan dalam ceritanya

Gambaran kemiskinan dalam cerpen "Nomer" diungkapkan secara jelas melalui tokoh-tokohnya. Gambaran kehidupan keluarga Doel Kamid menjadi gambaran kemiskinan sebuah keluarga. Gambaran kemiskinan tersebut dapat dilihat dari kutipan berikut.

Istananya yang kecil tanpa bilik telah penuh dengan asap rokok.

...di ruangan yang disekat dengan karung bekas tempat makanan ayam. Ragil, anaknya yang bungsu, sudah tiga hari ini panas badan. Belum diobati. Ditatapnya dalam-dalam secara bergantian, wajah-wajah yang siang tadi menyampaikan permintaan.
"Pak, kalau uang SPP belum dilunasi, Minah tidak boleh ikut semesteran" kata Minah. "Pak, baju seragamku sudah robek-robek. Aku malu sama teman-teman" giliran si Boimin merengek.

Belum lagi permintaan anaknya yang lain, biaya pengobatan si Ragil dan tagihan hutang yang menumpuk. (Jamaah, 1988).

Deskripsi rumah Doel Kamid menunjukkan bahwa keluarga Doel Kamid adalah keluarga miskin. Kata istana di awal kalimat tidak merujuk ke arti sebenarnya. Kata istana tidak merujuk tempat yang megah dan indah, tetapi sebuah hiperbola karena hanya sebuah tempat yang kecil tanpa bilik dan hanya disekat dengan karung bekas makanan ayam. Selain itu, gambaran kemiskinan tokoh Doel Kamid terlihat dari keadaan anaknya yang sakit, belum membayar SPP, baju seragam yang robek, dan utang yang menumpuk.

Selain cerpen "Nomer, cerpen "Tatkala Takbir Menggema" yang mengangkat tema kehidupan Ratih juga menyinggung persoalan kemiskinan. Sosok Rey yang menjadi pujaan Ratih ternyata seorang pejudi. Kegemaran berjudi sosok Rey mengakibatkan kondisi ekonomi Ratih hancur. Gambaran perjudian yang dilakukan oleh Rey dapat di lihat dalam kutipan berikut.

Satu-satunya perhiasanku terjual untuk makan dan biaya Rey ke sana-sini dengan alasan untuk mencari pekerjaan. Setelah perhiasanku habis Rey meninggalkanku. Aku dibiarkan dan ditinggalkan begitu saja. Akhirnya kuketahui juga bahwa Rey adalah seorang penjudi (Lestari, 1989).

Dari kutipan di atas terlihat bahwa judi yang dilakukan oleh Rey tidak menghasikan 
keuntungan finansial. Selain itu, judi yang dilakukan merusak keharmonisan antara Ratih dan Rey.

Persoalan kemiskinan juga tampak dalam cerpen "Suatu Sore di Pinggiran Desa". Masalah kemiskinan tampak saat Bidin yang harus menyisihkan separuh upahnya untuk melunasi utang dan harus menyiapkan dana untuk persiapan istri yang akan melahirkan. Selain itu, keperluan sekolah anaknya juga harus dipenuhi.

Utangmu sama boss sudah lunas, Din? tanya Muin setelah merasa suasana persoalan yang mereka hadapi adalah sama.

Bidin menarik nafas agak pendek, mengais tanah dengan ranting-ranting asam yang kering. "Belum” Jawabnya pelan. "Untuk mencicil utang itu aku hanya mengambil separo dari upahku setiap hari," lanjutnya berusaha tabah. Dalam pikirannya melintas bayangan istrinya yang lagi hamil serta anakanaknya yang selalu saja minta dibelikan buku. (Iskandar, 1988)

Kutipan di atas menunjukkan permasalahan ekonomi yang dialami Bidin. Kesulitan ekonomi keluarganya membuat Bidin harus berutang kepada majikannya. Upahnya sebagai pekerja tidak sebanding dengan keperluannya. Penghasilannya sebagai seorang pekerja tidak cukup untuk memenuhi kehidupan sehari-hari.

\subsection{Disorganisasi Keluarga}

Disorganisasi keluarga adalah perpecahan keluarga sebagai suatu unit karena anggota-anggotanya gagal memenuhi kewajibannya yang sesuai dengan peranan sosial (Soekanto, 2015:324). Dari ketiga cerpen di atas, disorganisasi keluarga muncul dalam cerpen "Tatkala Takbir Menggema". Bentuk disorganisasi keluarga dalam cerita digambarkan sebagai berikut.
Begitulah akhirnya Ratih memilih Rey dan meninggalkan orang tuanya tanpa pamit. Tetapi setelah di kota apa yang terjadi, ternyata Rey tak punya orang tua apalagi keluarga. Dan kami tinggal dalam sebuah rumah yang pantas disebut gubuk...

....Setelah perhiasanku habis Rey meninggalkan ku. Aku dibiarkan dan ditinggalkan begitu saja. Akhirnya ku ketahui juga bahwa Rey adalah seorang penjudi (Lestari, 1989).

Salah satu bentuk disorganisasi keluarga menurut Soekanto adalah kepergian kepala keluarga meninggalkan keluarga karena suatu alasan. Kepergian Rey meninggalkan Ratih ketika dapat dikatakan sebagai bentuk disorganisasi keluarga. Selain itu, bentuk hubungan di luar perkawinan dapat digolongkan sebagai disorganisasi keluarga meskipun secara yuridis dan sosial belum terbentuk keluarga (Soekanto, 2015:324). Tokoh Rey dan Ratih dalam cerita ini tidak digambarkan menikah secara resmi. Mereka hidup bersama tanpa ikatan perkawinan yang sah.

\subsection{Generasi Muda dalam Masyarakat Modern}

Masalah generasi muda pada umumnya ditandai dengan dua ciri yang berlawanan, yakni keinginan untuk melawan dan sikap yang apatis (Soekanto, 2015:325). Masalah generasi muda dalam masyarakat modern terdapat dalam cerpen "Tatkala Takbir Menggema". Gambaran sikap anak muda dalam masyarakat modern dapat dilihat dalam kutipan berikut.
"Ratih sayangku, kita akan pergi ke kota ke rumah orang tuaku"...
“Baik Ratih kau boleh memilih aku sebagai kekasihmu atau orang tuamu. 
Kalau memang kau tak mau, baik aku akan meninggalkanmu" ...

Begitulah akhirnya Ratih memilih Rey dan meninggalkan orang tuanya tanpa pamit. (Lestari, 1989).

Keputusan Ratih mengikuti kekasihnya dan meninggalkan kedua orang tuanya dapat digolongkan sebagai bentuk perlawanan anak muda kepada orang tua. Rey adalah tokoh yang mengajak Ratih untuk melakukan tindakan yang mengabaikan keberadaan orang tua dalam keluarga. Mengabaikan dan meninggalkan keluarga dapat dikatakan sebagai masalah generasi muda dalam masyarakat modern.

\subsection{Pelanggaran terhadap Norma-norma Masyarakat}

Pelanggaran terhadap norma-norma masyarakat meliputi pelacuran, delinkuensi anak-anak, alkoholisme, dan homoseksualitas (Soekanto, 2015:328-333). Dari beberapa norma masyarakat di atas, bentuk pelanggaran norma yang menonjol adalah pelacuran. Bentuk pelacuran diangkat dalam cerpen "Tatkala Takbir Menggema" yang menggambarkan tokoh Ratih sebagai seorang pelacur yang bertobat. Ratih menjalani kehidupan sebagai seorang pelacur untuk mengatasi persoalan ekonominya. Seorang anggota masyarakat yang terdesak oleh kebutuhan hidup dapat melanggar norma yang ada di masyarakat untuk memenuhi kebutuhan hidupnya. Gambaran sosok Ratih yang terhimpit persoalan ekonomi dapat dilihat dalam kutipan berikut.

Ratih tak dapat lagi pulang kampungnya. Ia tak punya uang sama sekali untuk ongkos. Akhirnya untuk mengisi perut Ratih menjalani suatu kehidupan yang baru. Kehidupan yang gelap. Mulai dari situlah maka Ratih menjalani hidupnya sebagai kupukupu malam. (Lestari, 1989)
Kutipan tersebut menunjukkan bagaimana Ratih terpaksa menjadi wanita kupukupu malam karena kemiskinan. Ketiadaan uang untuk memenuhi kebutuhan hidup membuat Ratih mengambil jalan pintas yang tidak sesuai dengan norma-norma agama dan masyarakat. Keputusan Ratih menjadi wanita malam untuk mengatasi kesulitan ekonominya adalah hal negatif yang tidak sesuai norma agama dan masyarakat.

\subsection{Kependudukan}

Masalah kependudukan akan menyebabkan terhambatnya peningkatan produktivitas dan kemakmuran penduduk secara menyeluruh. Masalahkependudukan terkait dengan pertumbuhan penduduk yang terlalu cepat dan angka kelahiran yang tinggi (Soekanto, 2015:331). Persoalan kependudukan diangkat dalam cerpen berjudul "Nomer". Gambaran masalah kependudukan dapat dilihat dalam kutipan berikut.

Matanya yang cekung karena kurang tidur memandang Minah, Boimin, Cipluk dan Rukun, keempat anaknya tidur tumpang tindih kaki dengan kepala, karena sempitnya ruangan. Sementara si Ragil tidur di pelukan ibunya.... (Jamaah, 1988).

Dalam kutipan di atas tokoh Doel Kamid digambarkan memiliki lima orang anak. Keberadaan lima orang anak dalam satu keluaga bertentangan dengan program pemerintah berkaitan dengan keluarga berencana. Kondisi keluarga dengan lima orang anak ini menyulitkan Doel Kamid untuk memenuhi kebutuhan hidup keluarganya.

\subsection{Lingkungan Hidup}

Lingkungan hidup dibedakan menjadi tiga, yaitu lingkungan fisik, biologis, dan sosial (Soekanto, 2015:342). Dari ketiga 
cerpen yang dikaji, masalah lingkungan lidup tersurat dalam cerpen "Suatu Sore di Pinggiran Desa". Gambaran masalah lingkungan hidup dapat dilihat dalam kutipan berikut.

Mereka tak pemah tahu, apakah penebangan-penebangan kayu itu disertai HPH atau tidak dan apa konsekuensi yang ditimbulkan oleh penebangan liar itu. Yang mereka tahu hanyalah mereka harus bekeja dan mendapat upah. Kalau tidak, mereka akan konyol. (Iskandar, 1988).

Dalam kutipan di atas terlihat bahwa para tokoh di dalam cerita tidak peduli dengan asal-usul kayu dan dampak dari penebangan liar. Ketidakpedulian manusia terhadap alam dan lingkungan dapat mempercepat kerusakan alam. Penebanganpenebangan hutan yang tidak terkendali tidak hanya merugikan manusia saja. Selain banjir dan berkurangnya pasokan oksigen karena hutan yang gundul, penebangan hutan secara liar juga dapat menghilangkan tempat tinggal dan sumber makanan satwasatwa di hutan. Di samping itu, kelestarian alam juga terancam dengan penebangan liar.

\subsection{Birokrasi}

Birokrasi merupakan organisasi yang bersifat hierarkis, yang ditetapkan secara rasional untuk mengordinasikan pekerjaan orang-orang untuk kepentingan pelaksanaan tugas-tugas administratif (Soekanto, 2015:342). Masalah birokrasi yang terdapat dalam cerpen "Suatu Sore di Pinggiran Desa" adalah ketika operasional perusahaan tempat Bidin bekerja harus berhenti karena perlengkapan administrasi yang kurang. Gambaran masalah birokrasi yang menyebabkan perusahaannya ditutup dapat dilihat dalam kutipan berikut.
"Ini ada petugas dari kehutanan" pak Kepala Desa menoleh pada kedua lelaki yang membawa stofmap.

Kedua laki-laki itu tersenyum penuh wibawa.

"Kami telah memeriksa berkas-berkas surat ijin pak Hamid, saya tidak bisa apa-apa, ternyata usaha ini tidak disertai surat yang lengkap. Jadi, sementara menunggu penyelesaian, kalian tidak usah bekerja dulu," jelas Kepala Desa. (Iskandar, 1988)

Kutipan tersebut menunjukkan bahwa birokrasi yang ada akan mematikan penghasilan Bidin sebagai pekerja. Sebagai buruh harian, tokoh Bidin akan diupah ketika bekerja dan ketika tidak ada pekerjaan berarti tidak ada penghasilan. Selama administrasi perusahaan belum lengkap, operasional perusahaan tempat Bidin bekerja akan berhenti. Hal itu menimbulkan masalah untuk para pekerja yang diupah harian. Upah yang mereka harapkan untuk memenuhi kebutuhan keluarga tidak akan mereka terima lagi selama tidak bekerja karena birokrasi yang mengharuskan operasional perusahaan berhenti.

\section{PENUTUP}

Gambaran masalah-masalah sosial yang dalam ketiga cerpen ini hampir seragam. Dari sembilan masalah sosial yang dikemukakan Soekanto, terdapat tujuh masalah yang tersurat dalam ketiga cerpen tersebut. Ketujuh masalah sosial yang muncul adalah masalah kemiskinan, disorganisasi dalam keluarga, disorganisasi keluarga, generasi muda dalam masyarakat modern, pelanggaran terhadap norma masyarakat, kependudukan, lingkungan hidup, dan birokrasi. Masalah sosial yang tidak terlihat adalah kejahatan dan peperangan. 
Masalah kemiskinan menjadi masalah sosial yang paling banyak muncul dalam cerpen yang diteliti. Ketiga cerpen mengungkapkan kemiskinan yang digambarkan melalui kehidupan para tokohnya. Selain kemiskinan, masalah diorganisasi, generasi muda dalam masyarakat modern, dan pelanggaran terhadap norma masyarakat hanya muncul dalam cerpen "Tatkala Takbir Menggema". Cerpen "Nomer" mengangkat masalah kependudukan dan kemiskinan. Cerpen "Suatu Sore di Pinggiran Desa" mengangkat masalah kemiskinan lingkungan hidup, dan birokrasi.

\section{DAFTAR PUSTAKA}

Damono, Sapardi Djoko. 1978. Sosiologi

Sastra Sebuah Pengantar Ringkas. Jakarta:

Pusat Pembinaan dan Pengembangan Bahasa Departemen Pendidikan dan Kebudayaan.

Endraswara, Suwardi. 2013. Metodologi Penelitian Sastra. Yogyakarta: CAPS

Faruk. 2012. Metodologi Penelitian Sastra

Sebuah Penjelajahan Awal. Yogyakarta: Pustaka Pelajar

Hartoko, Dick dan B. Rahmanto. 1986.

Pemandu di Dunia Sastra. Yogyakarta:

Kanisius
Mahayana, Maman S. 2006. Bermain dengan Cerpen. Apresiasi dan Kritik erpen Indonesia. Jakarta: PT Gramedia Pustaka Utama.

Nurgiyantoro, Burhan. 2005. Teori Pengkajian Fiksi. Yogyakarta: Gadjah Mada University Press.

Pernyata, Syafruddin dan Misman RSU. 2002. Antologi Menyambut Fajar; Catatan sastra. Yogyakarta: Dewan Kesenian Daerah Kalimantan Timur.

Pradopo, Rachmat Djoko dkk. (Jabrohim (Ed)). 2003. Metodologi Penelitian Sastra. Yogyakarta: Hanindita Graha Widya.

Ratna, Nyoman Kutha. 2009: Teori, Metode, dan Teknik Penelitian Sastra. Yogyakarta: Pustaka Pelajar.

Saraswati, Ekarini. 2003. Sosiologi Sastra Sebuah Pemahaman Awal. Malang: Bayu Media dan UMM Press.

Soekanto, Soerjono. 2015. Sosiologi Suatu Pengantar. Jakarta: PT RajaGrafindo Persada

Teeuw, A. 2013. Sastra dan Ilmu Sastra: Pengantar Teori Sastra. Bandung: Pustaka Jaya. 